\title{
Effect of cottonseed oil and ferrous sulfate in broiler diets on intestinal morphometry at 42 days of age
}

\author{
[Efeito de óleo de semente de algodão e sulfato ferroso em dietas de aves na morfometria \\ intestinal aos 42 dias de idade] \\ J.B.S. Oliveira ${ }^{1}$, V.B.S. Lima $^{2}$, H. P. A. Bastos ${ }^{2}$, D.C.N. Nascimento ${ }^{2}$, \\ L.R.B. Dourado ${ }^{1}$, G.J.B.C. Ferreira ${ }^{1}$ \\ ${ }^{1}$ Universidade Federal do Piauí - Campus Profa. Cinobelina Elvas - UFPI/CPCE - Bom Jesus, PI \\ ${ }^{2}$ Universidade Federal do Piauí - Campus Ministro Petrônio Portela - UFPI - Teresina, PI
}

\begin{abstract}
The aim of the study was to evaluate the intestinal morphometry of broilers at 42 days of age fed diets containing different levels of cottonseed oil, with and without addition of ferrous sulfate. A total of 560 male Ross chickens were used in a completely randomized design with a $4 \times 2$ factorial arrangement and five replications with 14 birds. The cottonseed oil levels tested were $0 \%, 2 \%, 4 \%$, and $6 \%$. At 42 days of age, one bird per replicate was collected for morphometric. Analyzed variables were villus height, crypt length and muscle wall thickness. The statistical analysis was performed using SAS, $\mathrm{P}=0.05$. In the duodenum and ileum, there was no significant effect of interaction between the treatments. In the jejunum, only the length of the crypt, the treatment with cottonseed oil $2 \%$, more ferrous sulfate resulted in lower values; however, the same oil content without ferrous sulfate led to a greater length, which was also observed in the treatment with $4 \%$ oil plus ferrous sulfate. Inclusion of cottonseed oil in broiler diets at 42 days of age does not impair their intestinal morphology. Supplementation with ferrous sulfate at these levels is unnecessary, since no improvement was observed in the intestinal morphometric.
\end{abstract}

Keywords: crypt, muscle wall, gossypol, villus

\section{RESUMO}

O objetivo de estudo foi avaliar a morfometria intestinal de aves aos 42 dias de vida alimentadas com dietas contendo níveis variados de óleo de semente de algodão com e sem adição de sulfato ferroso. Um total de 560 machos de aves Ross foram usadas em estudo randomizado com amostras $4 \times 2$ e 5 replicações com 14 aves. Os níveis de óleo de semente de algodão testados foram 0\%, 2\%, 4\%, e 6\%. Aos 42 dias de idade, um pássaro por replica foi coletado para morfometria. As variáveis analisadas foram altura de villus, comprimento de cripta, e espessura de parede muscular. A análise estatística foi realizada com SAS, $P=0,05$. Não houve efeito significativo de interação entre tratamentos no duodeno ou íleo. No jejuno, apenas o comprimento da cripta, no tratamento com óleo de semente de algodão a $2 \%$ com mais sulfato ferroso, apresentou valor mais baixo. No entanto, o mesmo valor de óleo sem sulfato ferroso resultou em maior comprimento, resultado percebido também com 4\% de óleo. Inclusão de óleo de semente de algodão em dietas de aves aos 42 dias de idade não causa danos à morfologia intestinal. Suplementação com sulfato ferroso não é necessário, já que não houve melhora em morfometria intestinal.

Palavras chave: criptas, parede muscular, gossypol, villus

\section{INTRODUCTION}

The main goal of modern poultry farming is to reduce production costs and increase productivity. For this purpose, producers make use of instruments such as genetics, management, and especially nutrition, since the diet is considered the main factor associated with production costs in commercial poultry farming (Carvalho and Fiúza 2008).

Recebido em 28 de abril de 2016

Aceito em 4 de agosto de 2017

E-mail: guilherme.ferreira@ufpi.edu.br 
One of the nutritional alternatives investigated today is the use of cotton by-products, which, due to their relatively chemical composition and low cost, are a financially viable option for diet formulation. However, the presence of gossypol limits their use at high proportions, as gossypol can be toxic at high levels (Prawirodigdo et al., 1997).

Signs of gossypol toxicity include loss of appetite; low weight gain; diarrhea; reduced hemoglobin count; degenerative alterations of the liver, spleen, and small intestine; besides yolk discoloration and reduced egg hatchability (Cheeke, 1989). However, the toxic action of gossypol can be minimized by heat and pressure in the processing of these products (Gadellha et al., 2014) and dietary addition of iron salts, which, when complexing with gossypol, make it innocuo (Nagalakshmi et al., 2007). The proportion soluble iron salts minimize the adverse effects of gossypol is of 2:1 (Waldroup and Kersey, 2002). Thus, when ferrous sulfate is added, animals tolerate higher levels of free gossypol, reaching 100ppm and even 200ppm for the initial and fattening phases (Barbosa and Gattás, 2004).

Of the cotton by-products, oil, is one of the least exploited in animal feed. Most of the researches are related to the use of cottonseed meal, indicating that it can be included in poultry diets (Erturk et al., 2004; Carvalho and Fiúza 2008), but in high amounts it can alter the performance (Świątkiewicz et al., 2016), meat quality and sensory analysis (Torres et al., 2011), hematological parameters (Thirumalaisamy et al., 2016), feed digestibility, enzymatic activity and intestinal morphometry (Sun et al., 2013). In relation to the oil, there is little information about the performance (Abdalqadir et al., 2014) and bird health (Aguiar et al., 2016); however, no information was found on the effect of inclusion of cotton oil on intestinal morphometry.

Given that one of the traits that characterize broilers as productive is high absorptive capacity per intestinal epithelium area, and that there are few studies addressing the influence of antinutritional factors on this tissue, the present investigation was conducted to evaluate the morphometry of the small intestine mucosa (villus height and crypt depth) in broilers at 42 days of age fed diets containing different levels of cottonseed oil, with and without addition of ferrous sulfate.

\section{MATERIAL AND METHODS}

The project was evaluated by the Ethics Committee on Animal Experimentation (CEEA/UFPI) and was approved under case no. $030 / 12$. The experiment was conducted in the poultry farming section of Colégio Técnico de Bom Jesus - CTBJ, on the Prof. ${ }^{\text {a }}$ Cinobelina Elvas campus of the Federal University of Piauí, located in Bom Jesus, PI, Brazil. A total of 560 male Ross chickens were used in a completely randomized design with a $4 \times 2$ factorial arrangement (four levels of oil, with or without ferrous sulfate) and five replications containing 14 birds per experimental unit.

At 22 days of age, birds were weighed and distributed according to their average weight into $2-\mathrm{m}^{2}$ cages equipped with poultry feeders and bell drinkers, located in a masonry shed covered with ceramic tiles and with cemented floor. The dividers between cages were made of wire, and curtains were used to control the temperature and drafts. Until the beginning of the experimental phase, at 22 days of age, birds were housed in a conventional shed and received diets based on corn and soybean meal according to the requirements described in Rostagno et al. (2011).

The tested cottonseed oil levels were 0,2 , 4, and $6 \%$, following the energy requirement of each phase as recommended by Rostagno et al. (2011) Ferrous sulfate $\left(\mathrm{Fe}_{2}\left(\mathrm{SO}_{4}\right)\right)$ was included at the dose of $0.1 \%$, following Santos et al. (2009).

Experimental diets (Table 1 and 2) were formulated to meet the nutritional requirements of broilers in the studied phase, as recommended by Rostagno et al. (2011). The cottonseed oil used was obtained by the mechanical pressing method, containing $12551 \mathrm{ppm}$ free gossypol and a gross energy content of $9120 \mathrm{Kcal} / \mathrm{kg}$. For the formulation, the ingredient composition followed Rostagno et al. (2011), except for cottonseed oil, in which the metabolizable energy determined in previous studies, of $7,732 \mathrm{Kcal} / \mathrm{kg}$ for crude cottonseed oil without ferrous sulfate and $8,270 \mathrm{Kcal} / \mathrm{kg}$ for the oil with ferrous sulfate, was considered. 
Water and feed were supplied ad libitum, and drinkers were washed twice daily to avoid heating and fermentation. A continuous lighting program (natural + artificial light) was adopted. At 42 days of age, 40 birds were collected - one per replication - for morphometric assessment.

Portions approximately 2cm long were collected from each of the intestinal segments (duodenum, jejunum, and ileum) of each bird. Immediately after sectioning the organ, the intestinal lumen was washed with distilled water to remove its content. All samples were identified and stored individually in Bouin's solution for 24h and later washed in running water and kept in 50\% alcohol until processing.

Table 1. Composition of experimental diets for broilers from 22 to 33 days of age

\begin{tabular}{|c|c|c|c|c|c|c|c|c|}
\hline \multirow{3}{*}{ Ingredient (\%) } & \multicolumn{8}{|c|}{ Treatment (cottonseed oil levels) } \\
\hline & \multicolumn{4}{|c|}{ without ferrous sulfate } & \multicolumn{4}{|c|}{ with ferrous sulfate } \\
\hline & $0 \%$ & $2 \%$ & $4 \%$ & $6 \%$ & $0 \%$ & $2 \%$ & $4 \%$ & $6 \%$ \\
\hline Corn & 67.471 & 66.049 & 60.896 & 55.743 & 67.368 & 65.690 & 60.179 & 54.668 \\
\hline Soybean meal 48\% & 27.738 & 27.979 & 28.854 & 29.729 & 27.773 & 28.040 & 28.976 & 29.911 \\
\hline Dicalcium phosphate & 1.232 & 1.233 & 1.239 & 1.245 & 1.232 & 1.233 & 1.239 & 1.245 \\
\hline Limestone & 0.880 & 0.878 & 0.872 & 0.865 & 0.880 & 0.878 & 0.872 & 0.865 \\
\hline Soybean oil & 1.274 & - & - & - & 1.343 & - & - & - \\
\hline Common salt & 0.455 & 0.456 & 0.458 & 0.461 & 0.455 & 0.456 & 0.458 & 0.461 \\
\hline Vitamin-mineral sup. ${ }^{1}$ & 0.400 & 0.400 & 0.400 & 0.400 & 0.400 & 0.400 & 0.400 & 0.400 \\
\hline DL-methionine & 0.233 & 0.234 & 0.239 & 0.244 & 0.233 & 0.234 & 0.239 & 0.244 \\
\hline L-lysine HCL & 0.213 & 0.208 & 0.190 & 0.172 & 0.213 & 0.208 & 0.190 & 0.168 \\
\hline Inert $^{2}$ & 0.100 & 0.558 & 2.849 & 5.140 & - & 0.757 & 3.346 & 5.936 \\
\hline Cottonseed oil & - & 2.000 & 4.000 & 6.000 & - & 2.000 & 4.000 & 6.000 \\
\hline Ferrous sulfate & - & - & - & - & 0.100 & 0.100 & 0.100 & 0.100 \\
\hline Total & 100.0 & 100.0 & 100.0 & 100.0 & 100.0 & 100.0 & 100.0 & 100.0 \\
\hline \multicolumn{9}{|c|}{ Nutritional composition } \\
\hline Linoleic acid (\%) & 2.190 & 1.477 & 1.385 & 1.293 & 2.224 & 1.470 & 1.372 & 1.274 \\
\hline Calcium (\%) & 0.750 & 0.750 & 0.750 & 0.750 & 0.750 & 0.750 & 0.750 & 0.750 \\
\hline Chlorine (\%) & 0.326 & 0.325 & 0.324 & 0.323 & 0.326 & 0.325 & 0.324 & 0.323 \\
\hline AME (Mcal/kg) ${ }^{3}$ & 3.050 & 3.050 & 3.050 & 3.050 & 3.050 & 3.050 & 3.050 & 3.050 \\
\hline Av. phosphorus (\%) & 0.335 & 0.335 & 0.335 & 0.335 & 0.335 & 0.335 & 0.335 & 0.335 \\
\hline Digestible lysine (\%) & 1.045 & 1.045 & 1.045 & 1.045 & 1.045 & 1.045 & 1.045 & 1.045 \\
\hline Dig. met. + cys. (\%) & 0.763 & 0.763 & 0.763 & 0.763 & 0.763 & 0.763 & 0.763 & 0.763 \\
\hline Crude fiber (\%) & 2.329 & 2.315 & 2.262 & 2.210 & 2.327 & 2.311 & 2.255 & 2.199 \\
\hline Potassium (\%) & 0.780 & 0.782 & 0.785 & 0.789 & 0.781 & 0.782 & 0.785 & 0.789 \\
\hline Crude protein (\%) & 19.000 & 19.000 & 19.000 & 19.000 & 19.000 & 19.000 & 19.000 & 19.000 \\
\hline Sodium (\%) & 0.200 & 0.200 & 0.200 & 0.200 & 0.200 & 0.200 & 0.200 & 0.200 \\
\hline Iron (mg/kg) & 152 & 152 & 152 & 152 & 352 & 352 & 352 & 352 \\
\hline Gossypol (mg/kg) & 0,000 & 251 & 502 & 753 & 0,000 & 251 & 502 & 753 \\
\hline
\end{tabular}

${ }^{1}$ Guaranteed levels per kg of product: folic acid - 162.50mg; chlorohydroxyquinoline - 7,500.00mg; vitamin A - 1,400,062.50IU; vitamin B1 - 388.00mg; vitamin B12 - 2,000.00mcg; vitamin B2 1,000.00mg; vitamin B6 - 520.00mg; vitamin D3 - 360,012.00IU; vitamin E - 2,500.00mg; vitamin K3 300.00mg; niacin - 7,000.00mg; salinomycin - 16,500mg; pantothenic acid - 2,600.00mg; choline chloride - 71.590mg; selenium - 75.00mg; ferrous sulfate $11.250 \mathrm{mg}$; manganese monoxide 18,740.00mg; copper sulfate - 1,996.00mg; iodine - 187.47mg; zinc - 17,500.00mg; ${ }^{2}$ Inert: sand.

${ }^{3}$ Apparent metabolizable energy of cottonseed oil $-7.732 \mathrm{Kcal} / \mathrm{kg}$ and $8.270 \mathrm{Kcal} / \mathrm{kg}$, with and without ferrous sulfate, respectively. ${ }^{4}$ Considering the iron content in the corn. soybean meal, dicalcium phosphate, vitamin-mineral supplement, and ferrous sulfate. 
Effect of cottonseed...

Table 2. Composition of experimental diets for broilers from 34 to 42 days of age

\begin{tabular}{|c|c|c|c|c|c|c|c|c|}
\hline \multirow{3}{*}{ Ingredient (\%) } & \multicolumn{8}{|c|}{ Treatment (cottonseed oil levels) } \\
\hline & \multicolumn{4}{|c|}{ without ferrous sulfate } & \multicolumn{4}{|c|}{ with ferrous sulfate } \\
\hline & $0 \%$ & $2 \%$ & $4 \%$ & $6 \%$ & $0 \%$ & $2 \%$ & $4 \%$ & $6 \%$ \\
\hline Corn & 71.089 & 69.640 & 64.487 & 59.335 & 71.089 & 69.281 & 63.770 & 58.2594 \\
\hline Soybean meal 48\% & 24.688 & 24.933 & 25.808 & 26.683 & 24.688 & 24.994 & 25.930 & 26.865 \\
\hline Dicalcium phosphate & 1.016 & 1.018 & 1.023 & 1.029 & 1.232 & 1.018 & 1.023 & 1.029 \\
\hline Limestone & 0.781 & 0.779 & 0.772 & 0.766 & 0.781 & 0.779 & 0.772 & 0.766 \\
\hline Soybean oil & 1.265 & - & - & - & 1.265 & - & - & - \\
\hline Common salt & 0.443 & 0.444 & 0.445 & 0.446 & 0.443 & 0.444 & 0.446 & 0.448 \\
\hline Vitamin-mineral sup. ${ }^{1}$ & 0.200 & 0.200 & 0.200 & 0.200 & 0.200 & 0.200 & 0.200 & 0.200 \\
\hline DL-methionine & 0.204 & 0.205 & 0.209 & 0.214 & 0.204 & 0.205 & 0.209 & 0.214 \\
\hline L-lysine HCL & 0.213 & 0.208 & 0.190 & 0.172 & 0.213 & 0.208 & 0.188 & 0.168 \\
\hline Inert $^{2}$ & 0.100 & 0.572 & 2.862 & 5.153 & - & 0.770 & 3.359 & 5.948 \\
\hline Cottonseed oil & - & 2.000 & 4.000 & 6.000 & - & 2.000 & 4.000 & 6.000 \\
\hline Ferrous sulfate & - & - & - & - & 0.100 & 0.100 & 0.100 & 0.100 \\
\hline Total & 100.0 & 100.0 & 100.0 & 100.0 & 100.0 & 100.0 & 100.0 & 100.0 \\
\hline \multicolumn{9}{|c|}{ Nutritional composition } \\
\hline Linoleic acid (\%) & 2.231 & 1.522 & 1.430 & 1.338 & 2.231 & 1.520 & 1.418 & 1.319 \\
\hline Calcium (\%) & 0.650 & 0.650 & 0.650 & 0.650 & 0.650 & 0.650 & 0.650 & 0.650 \\
\hline Chlorine (\%) & 0.319 & 0.318 & 0.317 & 0.316 & 0.319 & 0.318 & 0.317 & 0.316 \\
\hline $\operatorname{AME}(\mathrm{Mcal} / \mathrm{kg})^{3}$ & 3.100 & 3.100 & 3.100 & 3.100 & 3.100 & 3.100 & 3.100 & 3.100 \\
\hline Av. phosphorus (\%) & 0.290 & 0.290 & 0.290 & 0.290 & 0.290 & 0.290 & 0.290 & 0.290 \\
\hline Digestible lysine (\%) & 0.969 & 0.969 & 0.969 & 0.969 & 0.969 & 0.969 & 0.969 & 0.969 \\
\hline Dig. met. + cys. (\%) & 0.707 & 0.707 & 0.707 & 0.707 & 0.707 & 0.707 & 0.707 & 0.707 \\
\hline Crude fiber (\%) & 2.264 & 2.249 & 2.197 & 2.144 & 2.264 & 2.246 & 2.189 & 2.134 \\
\hline Potassium (\%) & 0.727 & 0.728 & 0.732 & 0.735 & 0.727 & 0.728 & 0.732 & 0.735 \\
\hline Crude protein (\%) & 17.800 & 17.800 & 17.800 & 17.800 & 17.800 & 17.800 & 17.800 & 17.800 \\
\hline Sodium (\%) & 0.195 & 0.195 & 0.195 & 0.195 & 0.195 & 0.195 & 0.195 & 0.195 \\
\hline Iron (mg/kg) ${ }^{4}$ & 117 & 117 & 117 & 117 & 326 & 326 & 326 & 326 \\
\hline Gossypol (mg/kg) & 0,000 & 251 & 502 & 753 & 0,000 & 251 & 502 & 753 \\
\hline
\end{tabular}

${ }^{1}$ Guaranteed levels per kg of product: folic acid - 162.50mg; chlorohydroxyquinoline - 7,500.00mg; vitamin A 14,000.00IU; vitamin B1 - 388.00mg; vitamin B12 - 2,000.00mcg; vitamin B2 - 1,000.00mg; vitamin B6 - 520.00mg; vitamin D3 - 1,600.00 IU; vitamin E - 2,500.00mg; vitamin K3 - 300.00mg; zinc - 70ppm; niacin - 7,000.00mg; salinomycin - 16,500mg; pantothenic acid - 2,600.00mg; choline chloride - 71.593.49mg; selenium - 75.00mg; ferrous sulfate 11.250mg; manganese monoxide - 18,750.00mg; copper sulfate - 2,000.00mg; iodine - 187.50mg; zinc oxide - 17,500.00mg; antioxidant additive - 25,000.00mg; halquinol - 7,500.00mg.

${ }^{2}$ Inert: sand.

${ }^{3}$ Apparent metabolizable energy of cottonseed oil - 7.732Kcal $/ \mathrm{kg}$ and $8.270 \mathrm{Kcal} / \mathrm{kg}$, with and without ferrous sulfate, respectively.

${ }^{4}$ Considering the iron content in the corn, soybean meal, dicalcium phosphate, vitamin-mineral supplement, and ferrous sulfate.

Samples underwent standard histological processing. The processed material was sectioned in a manual rotary microtome (Lupe ${ }^{\circledR}$ MRP-03) to a thickness of $4 \mu \mathrm{m}$ and subsequently 
stained with hematoxylin and eosin (HE), according to the methodology of Junqueira \& Junqueira (1983).

Using a trinocular optical microscope (Nova Optical Systems ${ }^{\circledR}$ ) equipped with a 5 megapixel digital camera (TOUPCAM ${ }^{\mathrm{TM}}$ ) for a photographic record of the images and subsequent measuring, 10 villi, 10 crypts, and the corresponding muscle wall thickness were selected for photographic recording and later measurement.

After the villi, crypts, and muscle wall region suitable for measuring were selected and photographed, measurements were taken using ToupView ${ }^{\circledR} 3.7$ software. Villi were measured from base to apex, with the limit being the region adjacent to the crypt area. Crypt length was obtained by measuring the crypt closest to the measured villus, as shown in Figure 1. The muscle wall thickness was measured from the muscularis to the serosa. The delimitation of these structures was guided by the description performed for broilers Cobb 500 (Sousa et al, 2015).

After complete collection of data, they were sent to Microsoft Excel 2013 for compilation of the data to be subjected to statistical analysis.

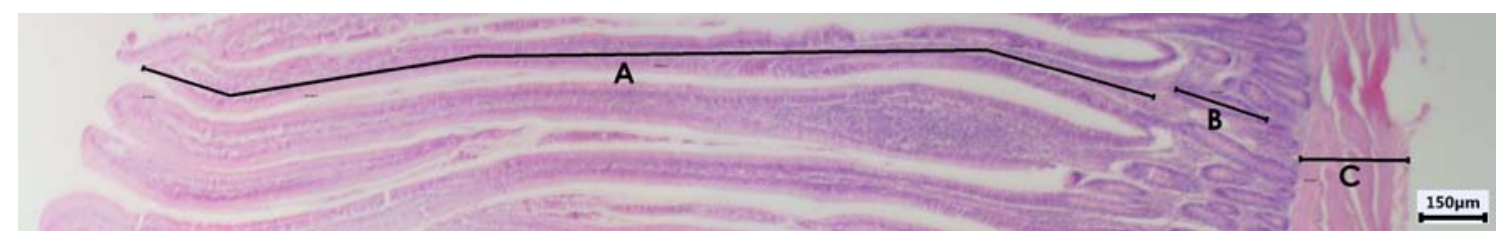

Figure 1. Photomicrograph demonstrating the measured structure. A shows villus length; B, crypt length; and $\mathrm{C}$, muscle wall thickness. Visualization under 4x objective lens.

The statistical analysis of the result was performed via the General Linear Models procedure (PROC GLM) of SAS (Statistical Analysis System, 9.0) software. To check the significance between treatment means, an SNK (Student-Newman-Keuls) test was applied at $\alpha=0.05$.

\section{RESULTS AND DISCUSSION}

The morphometric analysis of the duodenum (Table 3) did not show any effects of cottonseed oil level or ferrous sulfate inclusion, or of a significant interaction effect between treatments on any of the analyzed variables. Pelicano et al. (2007) studied the intestinal morphometry of broilers fed different additives and observed a significant interaction effect on villus height in the duodenum, jejunum, and ileum.

As regards the morphometric analysis of the jejunum (Table 2), no significant interaction effect was observed on the variables villus length and muscle wall thickness. Oliveira et al. (2000) studied the influence of the antinutritional factors of Leucaena and pigeon pea in broilers at 42 days of age and did not observe significant differences in villus height. According to Pollman (1986), the presence of pathogenic microorganisms causes lesions and thickening of the gastrointestinal tract walls, possibly as a result of the action of toxins that are released in these sites; these characteristics were not shown by the animals studied here.

The variable crypt length was significantly affected by the interaction, in which the presence of ferrous sulfate plus $2 \%$ cottonseed oil reduced this variable, and the same oil content without ferrous sulfate resulted in a longer crypt length than the other analyzed levels. However, analyzing the treatment with $4 \%$ oil, we observed that ferrous sulfate increased crypt length. According Siah et al. (2006), large stocks of iron in the tissues may lead to the formation of free radicals, which may or may not be associated with the reduction of crypt length found in this experiment. According to Pluske et al. (1997), a higher crypt length indicates greater cell proliferative activity, to ensure the adequate rate of villus epithelial cell renewal. Lima et al. (2016) studied the same levels of cottonseed oil as those in this study and concluded that the use of ferrous sulfate for chelation of gossypol in balanced diets for broilers fed diets containing 2 , 4 , and $6 \%$ cottonseed oil were similar to those of birds fed the control diet. 
Table 3. Mean values for villus height (VH), crypt length (CL), and muscle wall thickness (MWT) of the duodenum, in micrometers $(\mu \mathrm{m})$, of broilers receiving different levels of cottonseed oil (OL) with and without addition of ferrous sulfate (FS)

\begin{tabular}{|c|c|c|c|c|c|c|c|c|}
\hline \multirow[b]{2}{*}{ Variable } & \multirow{2}{*}{$\begin{array}{c}\text { Oil level } \\
\text { (\%) }\end{array}$} & \multicolumn{2}{|c|}{ Ferrous sulfate } & \multirow[b]{2}{*}{ Mean } & \multirow[b]{2}{*}{ CV (\%) } & \multirow[b]{2}{*}{ FS } & \multirow[b]{2}{*}{ OL } & \multirow[b]{2}{*}{$\mathrm{FS} * \mathrm{OL}$} \\
\hline & & With & Without & & & & & \\
\hline \multirow{5}{*}{$\begin{array}{l}\mathrm{VH} \\
(\mu \mathrm{m})\end{array}$} & 0 & 1272.8 & 1480.0 & 1376.4 & \multirow{5}{*}{22.18} & \multirow{5}{*}{0.5741} & \multirow{5}{*}{0.2468} & \multirow{4}{*}{0.7228} \\
\hline & 2 & 1435.3 & 1447.5 & 1441.4 & & & & \\
\hline & 4 & 1165.1 & 1325.1 & 1245.1 & & & & \\
\hline & 6 & 1635.7 & 1502.5 & 1569.1 & & & & \\
\hline & Mean & 1377.2 & 1438.8 & & & & & \\
\hline \multirow{4}{*}{$\begin{array}{l}\text { CL } \\
(\mu \mathrm{m})\end{array}$} & 0 & 93.7 & 96.3 & 95.0 & \multirow{4}{*}{24.14} & \multirow{4}{*}{0.1202} & \multirow{4}{*}{0.7598} & \multirow{4}{*}{0.1360} \\
\hline & 2 & 122.7 & 79.7 & 101.2 & & & & \\
\hline & 4 & 90.0 & 90.0 & 90.0 & & & & \\
\hline & 6 & 100.2 & 88.9 & 94.6 & & & & \\
\hline \multirow{6}{*}{$\begin{array}{c}\text { MWT } \\
(\mu \mathrm{m})\end{array}$} & Mean & 101.7 & 88.7 & & \multirow{6}{*}{30.93} & \multirow{6}{*}{0.8053} & \multirow{6}{*}{0.7523} & \multirow{6}{*}{0.2283} \\
\hline & 0 & 369.2 & 373.3 & 371.2 & & & & \\
\hline & 2 & 304.4 & 378.2 & 341.3 & & & & \\
\hline & 4 & 304.1 & 396.9 & 350.5 & & & & \\
\hline & 6 & 374.8 & 241.9 & 308.4 & & & & \\
\hline & Mean & 338.1 & 347.5 & & & & & \\
\hline
\end{tabular}

Means followed by common uppercase letters in the columns and lowercase letters in the rows do not differ by the SNK test $(\mathrm{P}<0.05)$; $\mathrm{CV}=$ coefficient of variation.

Table 4. Mean values for villus height (VH), crypt length (CL), and muscle wall thickness (MWT) of the jejunum, in micrometers $(\mu \mathrm{m})$, of broilers receiving different levels of cottonseed oil (OL) with and without addition of ferrous sulfate (FS)

\begin{tabular}{|c|c|c|c|c|c|c|c|c|}
\hline \multirow{2}{*}{ Variable } & \multirow{2}{*}{$\begin{array}{c}\text { Oil } \\
\text { level } \\
(\%)\end{array}$} & \multicolumn{2}{|c|}{ Ferrous sulfate } & \multirow[b]{2}{*}{ Mean } & \multirow{2}{*}{$\begin{array}{l}\text { CV } \\
(\%)\end{array}$} & \multirow{2}{*}{ FS } & \multirow{2}{*}{ OL } & \multirow{2}{*}{$\mathrm{FS} * \mathrm{OL}$} \\
\hline & & With & Without & & & & & \\
\hline \multirow{5}{*}{$\begin{array}{l}\text { VH } \\
(\mu \mathrm{m})\end{array}$} & 0 & 1405.5 & 1314.7 & 1360.1 & \multirow{5}{*}{22.51} & \multirow{5}{*}{0.8137} & \multirow{5}{*}{0.3058} & \multirow{5}{*}{0.766} \\
\hline & 2 & 1142.7 & 1128.3 & 1135.5 & & & & \\
\hline & 4 & 1016.1 & 1233.9 & 1125.0 & & & & \\
\hline & 6 & 1186.7 & 1171.0 & 1178.8 & & & & \\
\hline & Mean & 1187.7 & 1211.9 & & & & & \\
\hline \multirow{4}{*}{$\begin{array}{l}\text { CL } \\
(\mu \mathrm{m})\end{array}$} & 0 & 107.1 Aa & $74.8 \mathrm{Ab}$ & 90.9 & \multirow{5}{*}{26.46} & \multirow{5}{*}{0.0721} & \multirow{5}{*}{0.0887} & \multirow{4}{*}{$0.001 €$} \\
\hline & 2 & $40.1 \mathrm{Cb}$ & 89.3 Аа & 64.7 & & & & \\
\hline & 4 & $99.6 \mathrm{Ba}$ & 61.6 Ab & 80.6 & & & & \\
\hline & 6 & $110.5 \mathrm{ABa}$ & $71.3 \mathrm{Ab}$ & 90.9 & & & & \\
\hline \multirow{6}{*}{$\begin{array}{c}\text { MWT } \\
(\mu \mathrm{m})\end{array}$} & Mean & 89.3 & 74.2 & & & & & \multirow{6}{*}{0.4486} \\
\hline & 0 & 393.6 & 318.6 & 356.1 & \multirow{5}{*}{41.24} & \multirow{5}{*}{0.6787} & \multirow{5}{*}{0.1460} & \\
\hline & 2 & 448.6 & 286.7 & 367.6 & & & & \\
\hline & 4 & 451.1 & 522.9 & 487.0 & & & & \\
\hline & 6 & 253.4 & 321.9 & 287.6 & & & & \\
\hline & Mean & 386.6 & 362.5 & & & & & \\
\hline
\end{tabular}

Means followed by common uppercase letters in the columns and lowercase letters in the rows do not differ by the SNK test $(\mathrm{P}<0.05)$; $\mathrm{CV}=$ coefficient of variation.

Özdoğan et al. (2010) studied the effect of gossypol on the intestinal morphology of broilers and found that 62, 124, and 186ppm gossypol in the diet had no significant effect on villus height and width or crypt length. It should be stressed that the gossypol values used by those authors were much lower than the 251, 502, and 753ppm of the present study.

In another study Gadelha et al. (2014) studied the toxic effects of ingestion of gossypol present in cottonseed and its products, claiming to promote clinical poisoning, liver damage, male 
and female reproductive toxicity, and immunological impairment. These evaluations were performed and mice however changes in the immune system and liver lesions may severely compromise the development. However, it can be observed that gossypol included in the experimental diets with levels between 0 -
$753 \mathrm{mg} / \mathrm{kg}$, no alterations are observed in the intestinal structures, neither contributing nor harming the development of the animals

The morphometric analysis of the ileum (Table 5) did not show a significant interaction between treatments for the studied variables.

Table 5. Mean values for villus height (VH), crypt length (CL), and muscle wall thickness (MWT) of the ileum, in micrometers $(\mu \mathrm{m})$, of broilers receiving different levels of cottonseed oil (OL) with and without addition of ferrous sulfate (FS)

\begin{tabular}{|c|c|c|c|c|c|c|c|c|}
\hline \multirow[b]{2}{*}{ Variable } & \multirow{2}{*}{$\begin{array}{c}\text { Oil } \\
\text { level } \\
(\%)\end{array}$} & \multicolumn{2}{|c|}{ Ferrous sulfate } & \multirow[b]{2}{*}{ Mean } & \multirow{2}{*}{$\begin{array}{l}\text { CV } \\
(\%)\end{array}$} & \multirow[b]{2}{*}{ FS } & \multirow[b]{2}{*}{ OL } & \multirow[b]{2}{*}{ FS*OL } \\
\hline & & With & Without & & & & & \\
\hline \multirow{5}{*}{$\begin{array}{c}\mathrm{VH} \\
(\mu \mathrm{m})\end{array}$} & 0 & 920.6 & 1136.0 Аa & 1028.3 & \multirow{5}{*}{16.31} & \multirow{5}{*}{0.5922} & \multirow{5}{*}{0.4940} & \multirow{5}{*}{0.0771} \\
\hline & 2 & 966.4 & 1128.4 Аа & 1047.4 & & & & \\
\hline & 4 & 1183.3 & 1004.4 Aa & 1093.8 & & & & \\
\hline & 6 & 999.2 & 929.0 & 964.1 & & & & \\
\hline & Mean & 1017.3 & 1049.4 & & & & & \\
\hline \multirow{4}{*}{$\begin{array}{c}\text { CL } \\
(\mu \mathrm{m})\end{array}$} & 0 & 118.2 & 94.1 & 106.1 & \multirow{4}{*}{29.27} & \multirow{4}{*}{0.1973} & \multirow{4}{*}{0.4691} & \multirow{4}{*}{0.4845} \\
\hline & 2 & 120.0 & 132.1 & 126.0 & & & & \\
\hline & 4 & 120.5 & 87.6 & 104.0 & & & & \\
\hline & 6 & 118.3 & 102.8 & 110.5 & & & & \\
\hline \multirow{6}{*}{$\begin{array}{l}\text { MWT } \\
(\mu \mathrm{m})\end{array}$} & Mean & 119.2 & 104.1 & & \multirow{6}{*}{29.28} & \multirow{6}{*}{0.4429} & \multirow{6}{*}{0.4028} & \multirow{6}{*}{0.4395} \\
\hline & 0 & 332.1 & 327.8 & 329.9 & & & & \\
\hline & 2 & 413.2 & 405.0 & 409.1 & & & & \\
\hline & 4 & 295.6 & 450.3 & 372.9 & & & & \\
\hline & 6 & 437.5 & 427.3 & 432.4 & & & & \\
\hline & Mean & 369.6 & 402.6 & & & & & \\
\hline
\end{tabular}

Means followed by common uppercase letters in the columns and lowercase letters in the rows do not differ by the SNK test $(\mathrm{P}<0.05)$; $\mathrm{CV}=$ coefficient of variation.

Oliveira et al. (2008) used additives in broiler diets and observed that the muscle wall thickness was lower in birds fed diets without additives. Schwarz et al. (2002), however, tested diets containing additives and reported no differences in the muscle layer thickness of the intestinal wall of broilers as a result of treatments.

As described by Cunha, et al (2016), the dimensions of the intestinal wall components gradually reduced in the cranio-caudal direction, without interference from the diet administered. Cunha et al. (2016) et al. Demonstrate that the use of crude glycerin containing ethanol in its compaction results in the reduction of villi. The toxic effect of Gossypol did not cause this type of change.

Sousa, et al (2017) describes in his work that inflammatory processes resulting from the implementation of dietary additives are normal and evidence that despite these alterations in the gastrointestinal tract, the inflammatory process caused by the additive does not compromise the performance. This statement indicates that the toxicity of gossypol, which despite being known, did not compromise the intestinal absorption function.

\section{CONCLUSIONS}

Inclusion of $2 \%, 4 \%$, and $6 \%$ cottonseed oil in diets for broilers at 42 days of age does not compromise their intestinal morphology. Supplementation with ferrous sulfate to chelate the gossypol at these levels is unnecessary, since no improvement was observed in the intestinal morphometric indices of most treatments. 


\section{REFERENCES}

ABDALQADIR, M.O.; MOHAMMED, A.A.; MOHAMMAD, K.A. et al. The effects of different levels of dietary frying olein oil on broiler chickens performance. Int. J. Innovative Agric. \& Bio. Res., v.2, p.34-45, 2014.

AGUIAR, V.S.L.; DOURADO, L.R.B.; LOPES, J.B. et al.,. Cottonseed oil in diets for growing broilers. Rev. Bras. Zootec., v.45, p.208-218, 2016.

BARBOSA, F.F; GATTÁS, G. Farelo de algodão na alimentação de suínos e aves. Revista eletrônica Nutritime, v.1, p.147-156, 2004.

CARVALHO, F.M.; FIÚZA, M.A. Determinação de custos como ação de competitividade: estudo de um caso na avicultura de corte. Ciênc. Agrotec., v.32, p.908-913, 2008.

CHEEKE, P.R. (Ed.). Toxicants of plant origin. Boca Raton: CRC Press, 1989. v.4, p.123-190.

CUNHA, H.P.F.; SOUSA, D.C.; SANTOS, E.T.; et al. Histomorfometria do intestino delgado de frangos de corte (cobb 500®) suplementadas com glicerina bruta a 7\%. Acta Vet. Brasilica, v.10, p.238-245, 2016.

ERTURK, M.M., OZEN, N., CELIK, K. Effects of replacement of soybean meal by cottonseed meal on laying performance and haemoglobin levels in practical diets for breeder Japanese quail, Coturnix coturnix japonica. Asian Aust. J. Anim. Sci., v.17, 980-983, 2004.

GADELHA, I.C.N.; FONSECA, N.B.S.; OLORIS, S.C.S. Gossypol toxicity from Cottosseed Products. Sci. World J., v.2014 p.11, 2014.

JUNQUEIRA, L.C.U.; JUNQUEIRA, L.M.M.S. Técnicas básicas de citologia e histologia. São Paulo: Universidade de São Paulo, 1983. 123p.

LIMA, V.B.S.; DOURADO, L.R.B.; MACHADO, L.P. et al. Cottonseed oil in diets for broilers in the pre-starter and starter phases. PLoS ONE, v.11, n.1, 2016.

NAGALAKSHMI, D.; RAO, S.V.R.; PANDA, A.K.; SASTRY, V.R.B. Cottonseed meal in poultry diets: a review. J. Poult. Sci., v.44, p.119-134, 2007.
OLIVEIRA, M.C.; MARQUES, R.H.; GRAVENA, R.A.; MORAES, V.M.B. Morfometria do intestino delgado de frangos tratados com dietas adicionadas de mananoligossacarídeo e complexo enzimático. Biotemas, v.21, p.135-142, 2008.

OLIVEIRA, P.B.; MURAKAMI, A.E.; GARCIA, E.R.M.; Influência de fatores antinutricionais da Leucena (Leucaena leucocephala e Leucaena cunningan) e do feijão guandu (Cajanus cajan) sobre o epitélio intestinal e o desempenho de frangos de corte. Rev. Bras. Zootec., v.29, p.1759-1769, 2000.

ÖZDOĞAN, M.; WELLMANN, K.; PAKSUZ, E. Effect of gossypol on blood serum parameters and small intestinal morphology of male broilers. J. Anim. Physiol. Anim. Nutr., v.96, p.95-101, 2010.

PELICANO, E.R.L.; SOUZA, P.A.; SOUZA, H.B.A. et al. Morphometry and ultra-structure of the intestinal mucosa of broilers fed different additives. Braz. J. Poult. Sci., v.9, p.173-180, 2007.

PLUSKE, J.R.; HAMPSON, D.J.E.; WILLIAMS, I.H. Factors influencing the structure and function of the small intestine en the weaned pig: a review. Livest. Prod. Sci., v.51, p.215-236, 1997.

POLLMAN, D.S. Probiotics in pig diets. In: HARESIGN, W.; COLE, D.J.A. (Eds.). Recent advance in animal nutrition. Butterworth: London, 1986. p.193-205.

PRAWIRODIGDO, S.; BATTERHAM, E.S.; ANDERSEN, L.M. et al. Nitrogen retention in pigs given diets containing cottonseed meal or soybean meal. Anim. Feed Sci. Technol., v.67, p.205-211, 1997.

ROSTAGNO, H.S.; ALBINO, L.F.T.; DONZELE, J.L. et al. (Eds.). Tabelas brasileiras para aves e suínos: composição de alimentos e exigências nutricionais. 3.ed. Viçosa: Universidade Federal de Viçosa, 2011. 252p.

SANTOS, M.S.V.; ESPÍNDOLA, G.B.; LÔBO, R.N.B. et al. Desempenho e qualidade dos ovos de poedeiras comerciais submetidas às dietas com diferentes óleos vegetais. Rev. Bras. Saúde Prod. Anim., v.10, p.654-667, 2009. 
SCHWARZ, K.K.; FRANCO, S.G.; FEDALTO, L.M. et al. Efeitos de antimicrobianos, probióticos, prebióticos e simbióticos sobre o desempenho e morfologia do jejuno de frangos. In: da CONFERÊNCIA APINCO DE CIÊNCIA E TECNOLOGIA AVÍCOLA, 2002, Campinas. Anais... Campinas: [s.n.], 2002. p.75.

SIAH, C.W.; OMBIGA, J.; ADAMS, L.A. et al. Normal iron metabolism and the pathophysiology of iron overload disorders. Clin. Biochem. Rev., v.27, p.5-16, 2006.

SOUSA, D.C.; OLIVEIRA, N.L.A.; SANTOS, E.T. et al. Caracterização morfológica do trato gastrointestinal de frangos de corte da linhagem Cobb 500®1. Pesqui. Vet. Bras., v.35, p.61-68, 2015.

SOUSA, D.C.; OLIVEIRA, N.L.A.; SANTOS, E.T.; DOURADO, L.R.B.; FERREIRA, G.J.B.C. Avaliação macro e microscópica do trato digestório de frangos de corte alimentados com dieta contendo glicerina. Com Sci., v.8, p.59-68, 2017.

SUN, H.; TANG, J.W.; YAO, X.H.; WU, Y.F.; WANG, X; FENG, J. Effects of dietary inclusion of fermented cottonseed meal ongrowth, cecal microbial population, small intestinal morphology, and digestive enzyme activity of broilers. Trop. anim. health prod. v.45:987-993, 2013.
SWIATKIEWICZ, S.; ARCZEWSKA-WLOSEK A.; JOZEFIAK, D. The use of cottonseed meal as a protein source for poultry: an updated review. Worlds Poult Sci J, 2016.

THIRUMALAISAMY, G.; PURUSHOTHAMAN, M.R., KUMAR, P.V.; SELVARAJ, P. Effect of feeding cottonseed meal on some hematological and serum biochemical parameters in broiler birds. Vet. World, v.9, 723-727, 2016.

TORRES, T.R.; LÜDKE, M.C.M.M.; MACIEL, M.I.S. et al. Atributos sensoriais da carne de frangos alimentados com farelo de algodão extrusado pela análise descritiva quantitativa simplificada e pelo teste triangular. Revista Brasileira de Ciências Agrárias [en linea] 2011, 6 (Enero-Marzo): [Fecha de consulta: 19 de abril de 2018] Disponible en:<http://www.redalyc.org/articulo.oa?id=1190 18527024> ISSN 1981-1160.

WALDROUP, P.W.; KERSEY, J.H. Nutrient composition of cottonseed meal surveyed. Feedstuffs, v.74, p.11-12, 2002. 